\title{
SISTEM PERBURUAN LANDAK MONCONG PANJANG (Zaglossus bruijnii) PADA MASYARAKAT KAMPUNG WAIBEM DAN KAMPUNG SAUKOREM TAMBRAUW, PAPUA BARAT
}

TRESIA FRIDA AWAK, SEPUS FATEM*, \& AKSAMINA YOHANITA

Fakultas Kehutanan Universitas Papua

Jl. Gunung Salju, Manokwari, Papua Barat 98314

*Email: sepus_fatem@yahoo.com

\begin{abstract}
The objective of this research was to investigate hunting system of western long-beaked echidna (Zaglossus bruijnii) by Waibem and Saukorem Local Communities, Tambrauw Regency in Papua Province of Indonesia during July to August 2014. The observation technique and semi-structural interview were carried out by asking local people through questionnaire and analyzed by descriptive method. The result shows that local people in Waibem and Saukorem villagers generally do hunting for consumption, commercial/sale and hobby. The hunting method used by these communities were lasso, chopping knife, dog, and visual hunting. Hunting time of western long-beaked echidnais normally done after rain, crescent moon, and during night. Eco-tourism development is expected to increase the income of local people as well as reducing hunting pressure of this species.
\end{abstract}

Keywords: hunting system, Zaglossus bruijnii, western long-beaked echidna, Kampung Saukorem, Kampung Waibem.

\section{INTISARI}

Penelitian ini bertujuan untuk mengetahui sistem perburuan landak moncong panjang (Zaglossus bruijnii) oleh masyarakat kampung Waibem dan Saukorem, Kabupaten Tambrauw. Penelitian ini dilakukan di Kampung Waibem dan Saukorem selama 1 bulan, yaitu sejak bulan Juli-Agustus 2014. Penelitian ini menggunakan metode deskriptif dengan teknik observasi lapangan dan wawancara semi struktural yang mengacu pada daftar kuisioner. Hasil penelitian menunjukkan bahwa umumnya masyarakat Kampung Waibem dan Saukorem melakukan perburuan dengan 3 (tiga) tujuan, yaitu untuk dikonsumsi, dijual, dan sebagai hiburan. Masyarakat Kampung Waibem dan Saukorem berburu landak moncong panjang dengan menggunakan jerat, parang, bantuan anjing, dan berburu secara visual (bantuan mata). Waktu berburu landak moncong panjang adalah sehabis hujan, bulan sabit, dan pada malam hari. Pengembangan ekowisata berbasis satwa landak moncong panjang menjadi salah satu strategi untuk menambah pendapatan masyarakat pada kedua kampung serta secara perlahan-lahan mengurangi tingkat perburuan masyarakat.

Kata kunci: sistem perburuan, Zaglossus bruijnii, landak moncong panjang, Saukorem Village, Waibem Village. 


\section{PENDAHULUAN}

Papua merupakan salah satu provinsi yang terbesar dan terletak di kawasan timur Indonesia. Papua diketahui memiliki keanekaragaman flora dan fauna yang sangat melimpah, baik di daratan maupun di perairan yang tersebar luas pada pulau-pulau di Provinsi Papua, baik pulau besar maupun pulau kecil. Menurut Flannery (1995) terdapat 212 mamalia asli New Guinea, 15 spesies yang telah punah dan 13 spesies hasil introduksi. Satwa liar merupakan salah satu kekayaan alam yang mempunyai manfaat sangat penting terutama bagi masyarakat yang tinggal di sekitar hutan dimana satwa liar itu berada. Dalam memenuhi kebutuhan protein hewani keluarga, masyarakat lokal Papua masih memperoleh hasil daging dari perburuan. Salah satu hasil perburuan yaitu landak moncong panjang.

Menurut Peters dan Doria (1876) disitasi Fatem (2003) dan Opiang (2009); Petocs (1994); Baillie (2009) dijelaskan bahwa Zaglossus terdiri dari tiga spesies yaitu Zaglossus bruijnii yang terdapat di bagian barat New Guinea, Zaglossus bartonii terdapat di seluruh Cordillere tengah New Guinea dan pegunungan Huon Peninsula, dan Zaglossus attenboroughi yang telah punah diketahui hidup pada ketinggian puncak Pegunungan Cyclop Jayapura. Dari ketiga spesies ini salah satunya adalah landak moncong panjang (Zaglossus bruijinii) yang mendiami daerah pegunungan yang luas di Papua dari ketinggian 1.100-4.000 m dpl (Petocz, 1994) dan endemik di bagian wilayah Kepala Burung Pulau Papua seperti Pegunungan Arfak, Tambrauw, Fak fak, Wandamen dan Pulau Salawati (Menzies, 1991; Petocz, 1994). Dataran tinggi mempunyai peran penting bagi kehidupan satwa liar dan juga keberadaan masyarakat tradisional yang sering melakukan pemanfatan sumberdaya hayati, sebagaimana salah satunya adalah sumber protein hewani. Hal ini membuat masyarakat sangat cenderung untuk memanfaatkan satwa ini sebagai satwa buruan yang akan memberi dampak kepunahan. Secara ekologi wilayah Tambrauw merupakan daerah penyebaran landak moncong panjang di Pulau Papua (Petocz, 1994). Hal ini diperkuat lagi dari informasi masyarakat setempat yang mendiami Kampung Waibem dan Saukorem pada Distrik Abun dan Amberbaken, Kabupaten Tambrauw yang mengetahui akan adanya spesies ini.

Landak moncong panjang merupakan mamalia primitif yang masih hidup sampai dengan saat ini. Satwa ini terancam punah disebabkan beberapa faktor antara lain pola reproduksi dan ancaman perburuan secara tradisional (Menzies, 1991; Flanery 1995; Petoczs, 1994). Menurut The Zoological Society of London (2012), landak moncong panjang merupakan mamalia yang unik dan kurang terkenal karena sudah diambang kepunahan akibat aktifitas perburuan dan penggunaan lahan serta kegiatan pertambangan, pertanian, dan penebangan liar sehingga harus dilakukan tindakan konservasi yang tepat.

Di sisi lain, Kabupaten Tambrauw telah menetapkan misi pembangunan kelima yakni menjaga lingkungan dengan mewujudkan Tambrauw sebagai Kabupaten Konservasi pada tahun 2015-2016 (Asem et al., 2011). Dengan demikian, seluruh kegiatan pembangunan wajib menempatkan isu konservasi pada berbagai program dan kebijakan pemerintah daerah. Satwa ini perlu upaya konservasi sebagai maskot Pulau Papua di wilayah Tambrauw pada khususnya. Program konservasi yang dikembangkan perlu mempertimbangkan aspek pemanfaatan yang telah berlangsung secara turun-temurun dimana aspek sosial ekonomi dari spesies ini, khususnya pemanfaatannya belum terdata secara ilmiah. Sehingga, penelitian ini dilaksanakan dengan 
melakukan pendataan pada masyarakat Kampung Waibem dan Saukorem Kabupaten Tambrauw.

\section{BAHAN DAN METODE}

\section{Tempat dan Waktu Penelitian}

Penelitian ini dilakukan di Kampung Waibem dan Saukorem, Kabupaten Tambrauw dan berlangsung selama 1 bulan, yaitu Juli-Agustus 2014. Subyek penelitian adalah masyarakat lokal Kampung Waibem dan Saukorem yang kesehariannya melakukan aktifitas perburuan, tokoh masyarakat dan yang mendiami Kampung Waibem dan Saukorem. Obyek penelitian adalah landak moncong panjang.

\section{Alat dan Bahan}

Alat yang digunakan antara lain kamera digital untuk pengambilan gambar, tape recorder digunakan untuk merekam wawancara dengan responden, buku tulis dan papan lapangan guna pencatatan data wawancara lainnya. Bahan dalam penelitian ini adalah kuisioner yang digunakan untuk melakukan pengambilan data responden dan bahan kontak berupa rokok dan pinang untuk memudahkan diskusi dan pengggalian informasi pada masyarakat lokal.

\section{Metode Pengambilan Data}

Data penelitian diambil menggunakan metode deskriptif dengan teknik observasi lapangan dan wawancara semi struktural sesuai daftar kuisioner. Jumlah responden yang digunakan dalam wawancara sebanyak 10 kepala keluarga (KK) dari total jumlah kepala keluarga Kampung Waibem 62 KK dan Saukorem 74 KK yang melakukan kegiatan berburu. Responden yang akan diwawancarai termasuk kepala desa dan masyarakat yang melakukan perburuan.

\section{Variabel Pengamatan}

Sistem perburuan, antara lain : tujuan berburu, teknik atau cara berburu masyarakat, peralatan berburu yang digunakan, cara penangkapan landak moncong panjang, jumlah orang/personil yang diperlukan, lokasi berburu, frekuensi berburu, waktu dan keadaan cuaca berburu, metode berburu. Sistem konservasi tradisional berupa teknik dan cara serta sanksi.

\section{HASIL DAN PEMBAHASAN}

\section{Aktivitas Berburu}

Masyarakat kampung Waibem dan Saukorem melakukan perburuan untuk dikonsumsi sendiri atau dijual untuk menambah pendapatan ekonomi dan sebagai hiburan. Dari hasil wawancara di lapangan dijelaskan bahwa pada satwa khususnya landak moncong panjang tidak dijual melainkan hanya untuk dikonsumsi untuk menambah gizi masyarakat di kedua kampung ini. Menurut Pattiselanno (2004), pemanfaatan untuk tujuan konsumsi mempunyai kontribusi yang signifikan terhadap ketersediaan protein hewani masyarakat di daerah pedalaman.

Peralatan yang digunakan dalam perburuan landak moncong panjang adalah jerat dan parang. Parang dalam bahasa Saukorem (Jet) dan bahasa Waibem (Nyom), sedangkan jerat dalam bahasa Saukorem (Nitum) dan bahasa Waibem (Buss). Masyarakat tidak menggunakan panah, tombak, atau senapan angin karena hewan ini dianggap mudah untuk ditangkap. Alat berburu dibuat dari bahan yang mudah diperoleh dari hutan atau wilayah sekitarnya. Cara dan fungsi penggunaan alat berburu berbeda tergantung dari jenis satwa yang diburu maupun teknik berburu. Satwa ini berjalan sangat lambat dan tidak menyusahkan pemburu dalam penangkapan. 


\section{Teknik Menangkap Tradisional Landak Moncong Panjang}

Pada umumnya masyarakat kampung Waibem dan Saukorem mengenal 3 teknik menangkap secara tradisional yaitu membuat jerat lubang, berburu secara visual (bantuan mata), dan berburu dengan bantuan anjing.

\section{Jerat lubang}

Penangkapan dengan menggunakan jerat lubang, diawali dengan pengamatan jejak atau bekas kaki landak moncong panjang. Setelah diketahui jejak landak moncong panjang, daerah tersebut dijadikan tempat pembuatan jerat (Gambar 1). Pemasangan jerat untuk landak moncong panjang dilakukan pada siang hari dan dibuat di hutan sekitar kebun. Jerat lubang paling umum disukai karena lebih praktis dalam membuatnya, demikian juga bahan yang digunakan mudah diperoleh dari hutan. Jerat lubang terdiri dari :

1. Kayu penjepit dua buah, satu ditancapkan di atas lubang galian, dan satunya lagi di bawah lubang galian berfungsi untuk mengait anak tali

2. Kedalaman lubang $\pm 5 \mathrm{~cm}-10 \mathrm{~cm}$

3. Lebar lubang galian $30 \mathrm{~cm}$
4. Panjang lubang galian $\pm 40 \mathrm{~cm}$

5. Panjang tali ayunan $3-4 \mathrm{~m}$

6. Kayu para-para perangkap $5-6$ buah

7. Kayu langsat sebagai kayu ayunan perangkap

Selanjutnya waktu pemeriksaan jerat biasanya para pemburu dari Kampung Waibem dan Saukorem menunggu selama kurang lebih 5-7 hari. Setelah itu, jerat diperiksa sekali dalam seminggu, tergantung perolehan hasil buruan.

\section{Berburu secara visual (bantuan mata)}

Berburu secara visual artinya melihat tanda-tanda jejak landak moncong panjang. Perburuan ini dilakukan pada siang dan malam hari secara langsung dan sudah diketahui oleh setiap pemburu di Kampung Waibem dan Saukorem pada hutan alam. Pemburu sudah memiliki pengalaman dalam mengenal jenis hewan, membaca fenomena alam, membaca musim, memahami makanan binatang di hutan, sampai bagaimana menangkap dan membunuh hewan buruan secara cepat dan mudah. Jejak dan tanda-tanda dimana landak moncong panjang bersembunyi dan mencari makan sudah dikenal oleh pemburu secara visual. Pengenalan itu

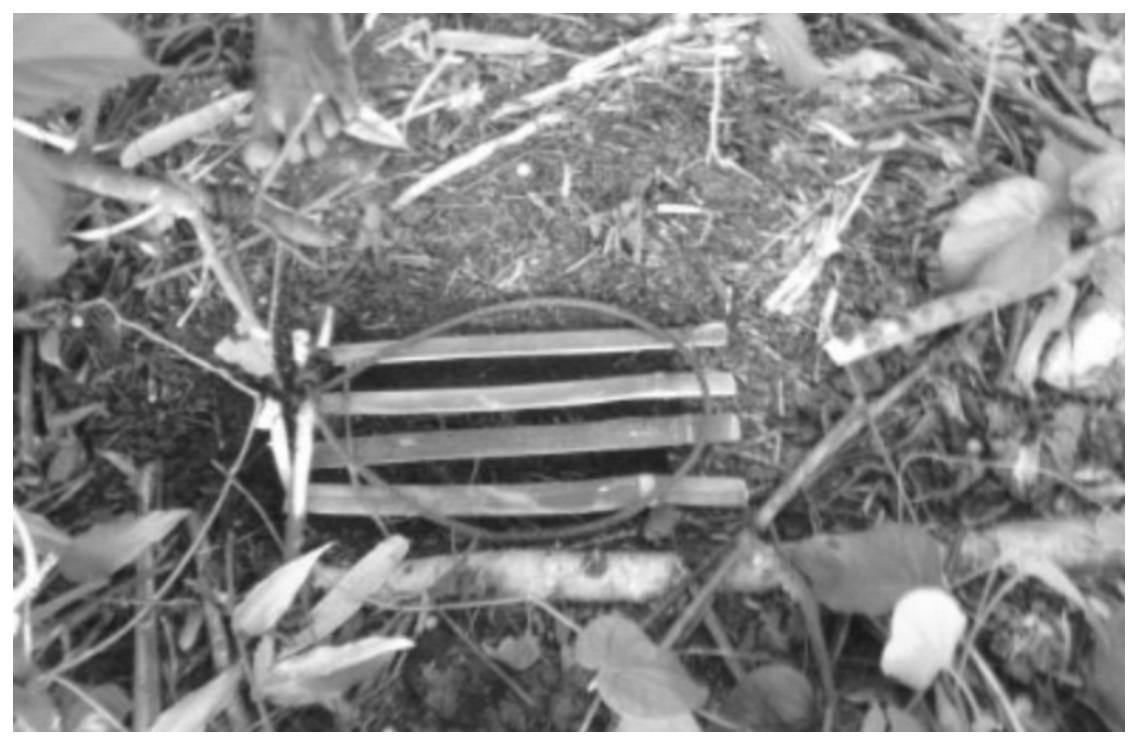

Gambar 1. Model jerat yang di gunakan menangkap satwa landak moncong panjang 
sangat membantu pemburu disertai dengan bantuan anjing berburu dan jerat.

\section{Berburu dengan bantuan anjing}

Teknik ini sering digunakan masyarakat bagi anjing peliharaannya yang sudah dilatih dan dipersiapkan terlebih dulu secara fisik untuk berburu. Kegiatan berburu yang dilakukan dari pagi-sore, sore-malam, dan malam-pagi pada lokasi-lokasi di dalam hutan. Landak moncong panjang biasanya ditemukan dekat kayu-kayu tumbang yang telah membusuk, batu-batu besar dan lubang-lubang galian yang pernah dibuat olah hewan ini.

Pengamatan di lapangan menunjukkan bahwa dalam melakukan kegiatan menggunakan anjing, perlakuan yang dilakukan menurut kebiasaan dan pengetahuan yang dimiliki masyarakat Kampung Waibem dan Saukorem adalah memberi ramuan. Ada dua jenis ramuan yang dikenal oleh masyarakat di kedua kampung ini, yaitu: tali hutan (Meremia sp.) dan ramuan halia/jahe merah (Zingiber officinale). Tali hutan bagian yang digunakan adalah bagian batang dan ini biasanya digunakan masyarakat dengan cara meniup pada bagian hidung anjing, mulut anjing dan dipukul pada bagian perut anjing. Ramuan berupa halia/jahe merah digunakan dengan cara rimpahan jahe merah diparut dan direndam dengan air asin sekitar 5 menit kemudian sari jahe merah tersebut disaring dan diusapkan atau disiram pada bagian hidung anjing. Tujuan dari pemberian ramuan ini adalah untuk merangsang keluarnya lendir dari hidung agar penciuman anjing tajam dan tetap hangat berada di daerah dingin atau ketika melakukan kegiatan berburu pada musim hujan dan pada waktu pagi hari. Kegiatan berburu dengan menggunakan anjing ini telah terlatih, dan telah dipraktekkan secara turun-temurun, karena mudah dan praktis dalam melakukannya dan merupakan pengetahuan tradisional.

\section{Jumlah Anggota Berburu}

Jumlah anggota keluarga pada Kampung Waibem adalah 62 kepala keluarga (KK) terdiri dari 217 jiwa dan pada Kampung Saukorem adalah 74 kepala keluarga dan terdiri atas 309 jiwa. Dari data penduduk ini diambil $10 \mathrm{KK}$ dari jumlah $\mathrm{KK}$ pada setiap kampung yang kesehariannya melakukan aktifitas perburuan secara berkelompok dapat dilihat pada Tabel 1.

Tabel 1 menyajikan jumlah anggota berburu pada Kampung Waibem dalam satu kelompok maksimal 5-10 orang dan di atas 10 orang berkisar (40\%), sedangkan Kampung Saukorem dalam satu kelompok maksimal $=10$ orang berkisar $(50 \%)$. Hal ini berpengaruh besar terhadap perburuan, selain itu juga dapat membantu dalam menangkap, mengejar, memasang jerat dan memikul hasil buruan serta sebagai teman dalam melakukan kegiatan berburu. Aktifitas berburu melibatkan jumlah anggota pada tempat yang jauh dengan medan berburu yang berat. Selain itu anggota berburu ini didasarkan oleh

Tabel 1. Sebaran menurut jumlah anggota berburu landak moncong panjang.

\begin{tabular}{ccccc}
\hline Jumlah Anggota Berburu & \multicolumn{2}{c}{ Jumlah KK } & \multicolumn{2}{c}{ Nisbah (\%) } \\
\cline { 2 - 5 } (Jiwa) & $\begin{array}{c}\text { Kampung } \\
\text { Waibem }\end{array}$ & $\begin{array}{c}\text { Kampung } \\
\text { Saukorem }\end{array}$ & $\begin{array}{c}\text { Kampung } \\
\text { Waibem }\end{array}$ & $\begin{array}{c}\text { Kampung } \\
\text { Saukorem }\end{array}$ \\
\hline $3-5$ & 2 & 3 & 20 & 30 \\
$5-10$ & 4 & 2 & 40 & 20 \\
$>10$ & 4 & 5 & 40 & 50 \\
Total & 10 & 10 & 10 & 100 \\
\hline
\end{tabular}

Sumber : Data Primer, 2014 
hubungan keluarga atau kekerabatan di antara sesamanya.

\section{Lokasi Berburu}

Pada umumnya masyarakat Kampung Waibem dan Saukorem berada di hutan sekitar kampung. Lokasi berburu biasanya pada hutan primer, hutan sekunder, kebun-kebun masyarakat, dan daerah aliran sungai. Menurut informasi yang diperoleh di lapangan lokasi berburu landak moncong panjang harus ditempuh dengan berjalan kaki jauh ke hutan belantara dan berjam-jam sesuai dengan lokasi yang dianggap sesuai untuk mendapatkan satwa ini. Penemuan lokasi berburu dilakukan dengan mengetahui habitat dari landak moncong panjang, misalnya harus berjalan di dalam hutan yang berbatu-batu dan bergunung-gunung, dan lantai hutan lembab serta galian lubang-lubang dimana landak moncong panjang mencari makan dan beristirahat.

\section{Frekuensi Berburu}

Frekuensi berburu oleh masyarakat Kampung Waibem dan Saukorem biasanya bervariasi.
Masyarakat melakukan perburuan seminggu sekali atau lebih. Data mengenai frekuensi berburu responden Kampung Waibem dan Saukorem dapat dilihat pada Tabel 2.

Tabel 2 menjelaskan bahwa frekuensi perburuan satwa pada kedua kampung berbeda. Dari hasil pengamatan di lapangan bahwa frekuensi berburu untuk masyarakat Kampung Waibem 2 kali dalam seminggu berkisar 60\%, sedangkan Kampung Saukorem adalah sekali dalam seminggu berkisar 50 $\%$. Hal tersebut dilakukan karena pada masyarakat Kampung Waibem dan Saukorem adalah kelompok masyarakat yang pada umumnya atau mata pencaharian mereka berburu, sedangkan masyarakat yang frekuensi berburunya hanya satu kali umumnya adalah mereka yang berstatus sebagai petani, nelayan, dan Pegawai Negeri Sipil (PNS).

Biasanya pemburu menggunakan alat berburu jerat dimana dalam seminggu aktifitas mereka hanya melakukan pengecekan terhadap jerat yang dipasang tanpa melakukan perburuan dan waktu sisa mereka dimanfaatkan. Masyarakat yang memiliki frekuensi berburu lebih dari 3 kali dalam seminggu berkisar

Tabel 2. Sebaran frekuensi berburu landak moncong panjang

\begin{tabular}{ccccc}
\hline \multirow{2}{*}{$\begin{array}{c}\text { Frekuensi } \\
\text { (Minggu) }\end{array}$} & \multicolumn{2}{c}{ Jumlah KK } & \multicolumn{2}{c}{ Nisbah $(\%)$} \\
\cline { 2 - 5 } & $\begin{array}{c}\text { Kampung } \\
\text { Waibem }\end{array}$ & $\begin{array}{c}\text { Kampung } \\
\text { Saukorem }\end{array}$ & $\begin{array}{c}\text { Kampung } \\
\text { Waibem }\end{array}$ & $\begin{array}{c}\text { Kampung } \\
\text { Saukorem }\end{array}$ \\
\hline 1 kali & 3 & 5 & 30 & 50 \\
2 kali & 6 & 3 & 60 & 30 \\
3 kali & 1 & 2 & 10 & 20 \\
Total & 10 & 10 & 100 & 100 \\
\hline
\end{tabular}

Tabel 3. Waktu aktifitas berburu landak moncong panjang

\begin{tabular}{ccccc}
\hline Waktu & \multicolumn{2}{c}{ Jumlah KK } & \multicolumn{2}{c}{ Nisbah $(\%)$} \\
\cline { 2 - 5 } Berburu & $\begin{array}{c}\text { Kampung } \\
\text { Waibem }\end{array}$ & $\begin{array}{c}\text { Kampung } \\
\text { Saukorem }\end{array}$ & $\begin{array}{c}\text { Kampung } \\
\text { Waibem }\end{array}$ & $\begin{array}{c}\text { Kampung } \\
\text { Saukorem }\end{array}$ \\
\hline $\begin{array}{c}\text { Subuh-Pagi } \\
03.00-08.00 \text { WIT }\end{array}$ & 5 & 4 & 50 & 40 \\
Malam & 5 & 6 & 50 & 60 \\
$20.00-24.00$ WIT & 10 & 10 & 100 & 100 \\
Total & & & & \\
\hline
\end{tabular}


10\%. Hal tersebut karena sumber pendapatan utamanya adalah dengan melakukan perburuan setiap saat sehingga hasil perburuan yang diperoleh sudah siap dibeli oleh penadah daging di daerah setempat dan juga secara langsung dapat dijual keluar kampung.

\section{Waktu Aktifitas Berburu}

Waktu berburu yang biasa dilakukan oleh masyarakat Kampung Waibem dan Saukorem tidak ditentukan secara pasti. Umumnya untuk berburu landak moncong panjang dimulai pada malam hari pukul 20.00-24.00 WIT dan pada subuh sampai pagi hari pada pukul 03.00-08.00 WIT.

Tabel 3 menjelaskan bahwa sebagian besar responden pada kedua kampung ini melakukan perburuan landak moncong panjang pada malam hingga pagi hari. Hal ini terkait oleh waktu dimana landak moncong panjang beraktifitas. Jumlah waktu yang digunakan di dua kampung relatif sama. Dengan jumlah responden pada kampung Waibem berkisar 6 responden dan 50\% masyarakat berburu dari malam hari hingga pagi, sedangkan kampung Saukorem terdiri dari 5 responden dan $60 \%$ masyarakat berburu pada malam hari. Satwa ini dapat ditemukan pada keadaan cuaca tertentu seperti pada malam hari sehabis hujan, dan saat bulan sabit.

\section{Pemanfaatan Hasil Buruan Landak Moncong Panjang}

Berdasarkan hasil yang didapat di lapangan, masyarakat Kampung Waibem dan Saukorem memanfaatkan daging dari landak moncong panjang. Di lain pihak, bulu, duri, kuku, dan bagian tubuh lainnya tidak dimanfaaatkan.

Untuk jumlah hasil buruan pada dasarnya satwa ini tergantung pada keadaan cuaca dan waktu berburu. Jumlah hasil buruan yang paling cepat didapat yaitu pada malam hari hingga pagi hari. Masyarakat yang berburu satwa pada saat bulan sabit dan keadaan cuaca habis hujan pada malam hari biasanya menemukan 3-5 ekor landak moncong panjang. Akan tetapi bukan menjadi target utama masyarakat melainkan satwa ini hanya secara kebetulan masyarakat menemukannya, seperti terkena jerat, digigit anjing, dan dilihat secara langsung, sehingga masyarakat tidak memperjualbelikan hanya dikonsumsi untuk menambah gizi dalam tubuh (Gambar 2).

\section{Sistem Konservasi Tradisional}

Masyarakat Kampung Waibem dan Saukorem dalam mempertahankan kearifan lokal sudah mengalami perubahan ditinjau dari adat dan norma yang berlaku, khususnya menyangkut kepercayaan-kepercayaan terhadap hewan yang dianggap
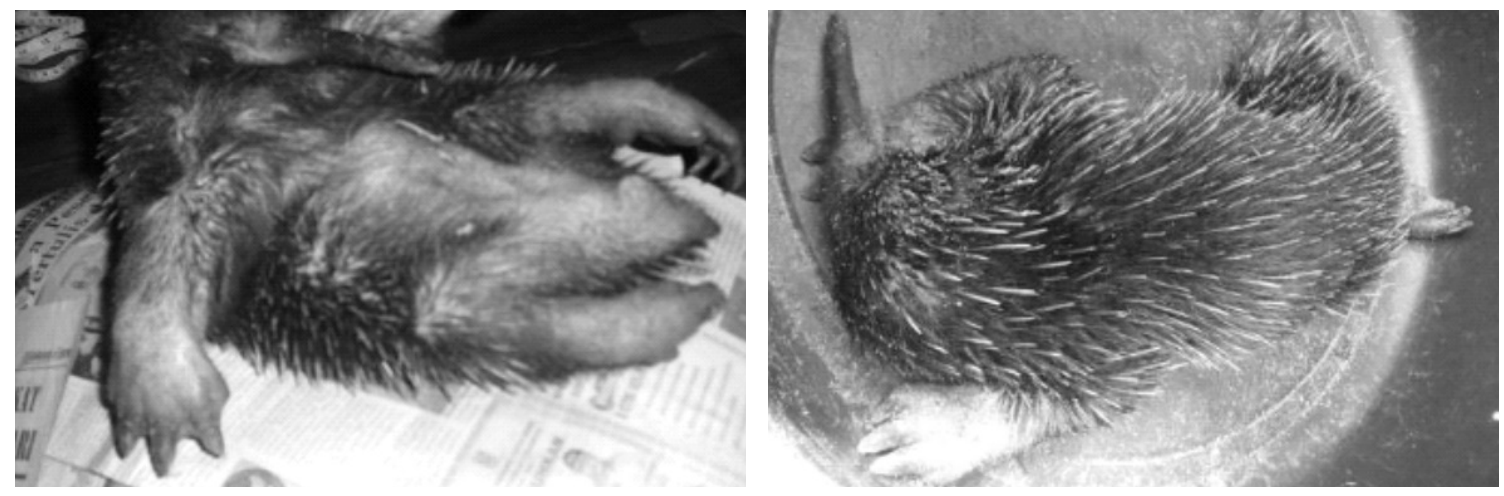

Gambar 2. Landak moncong panjang 
keramat serta kegiatan upacara adat yang dilakukan sebelum atau sesudah berburu.

Masyarakat Kampung Waibem pada umumnya tidak memiliki aturan baku yang ditetapkan dalam hal konservasi satwa. Namun dalam melakukan kegiatan perburuan masih dilakukan secara tradisional. Alat yang digunakan masih menggunakan senjata tradisional seperti busur dan anak panah, tombak, parang, serta jerat. Tidak diperbolehkan menggunakan senjata api karena akan mengganggu kehidupan dan menurunkan populasi dari satwa dalam hal buruan.

Masyarakat kampung Saukorem dalam hal konservasi satwa dan tindakan perburuan masyarakat menerapkan larangan atau sumpah untuk tidak melakukan kegiatan perburuan atau mengambil hasil hutan dalam jangka waktu tertentu pada daerah-daerah yang sudah ditentukan. Alat yang digunakan dalam kegiatan perburuan masih alat tradisional dan juga bisa menggunakan senjata api yang dilakukan pada bulan-bulan yang telah disepakati. Hal ini memberi hasil yang memuaskan bagi kedua kampung ini sehingga satwa liar bisa berkembang biak dan dapat dijumpai di sekitar kampung meskipun ada beberapa tempat yang sudah terlihat punah.

Untuk peraturan adat atau larangan tentang perburuan yang sudah dilakukan sejak lama dari leluhur dan tidak boleh dilanggar oleh masyarakat pada saat menangkap landak moncong panjang. Masyarakat tidak boleh mengeluarkan kata-kata yang tidak pantas atau kata-kata kotor dari mulut pemburu terhadap satwa tersebut. Hal ini akan membuat bencana berupa banjir atau hujan. Menurut masyarakat Waibem, kalau membawa satwa ini dengan perahu motor laut, satwa ini tidak boleh bersentuhan dengan hewan lain. Ini akan mengakibatkan bencana alam seperti angin, badai,

gelombak laut, bahkan pemburu akan hilang dengan perahu di tengah laut dan meninggal dunia. Untuk mengkonsumsi hewan ini pun masyarakat Waibem tidak selalu mengkonsumsi hewan ini karena hewan ini akan membuat badan terasa lemas dan malas-malasan. Berbeda dengan masyarakat Saukorem yang melarang mengkonsumsi hewan ini khususnya pada anak-anak pada usia 1-10 tahun karena dipercaya bisa membuat sikap anak-anak ini melawan terhadap orang tua.

Upaya-upaya konservasi yang dilakukan masyarakat pada kedua kampung ini khususnya untuk pelestarian habitat landak moncong panjang belum terlaksanakan dengan baik. Karena adanya aturan baku atau sah yang diterapkan, beberapa satwa sudah dilindungi berdasarkan kesepakatan bersama seperti cenderawasih kuning (Paradisea minor), kakatua raja (Probosciger aterrimus), rangkong Papua (Rhyticeros plicatus), nuri (Chalcopsitta atra) dan dara mahkota (Gaura Cristata). Untuk reptil adalah penyu belimbing (Dermochelys coriacea), penyu sisik (Eretmochelys imbricata), penyu sisik semu (Lepidochelys olivacea), dan penyu hijau (Chelonia mydas). Bentuk larangan yang dibuat adalah larangan terhadap pengambilan satwa liar tersebut. Untuk masyarakat Saukorem akan diberikan sanksi berupa pembayaran uang tunai sebesar Rp. 5.000.000,00 yang telah disepakati apabila melanggar peraturan atau sumpah untuk pengambilan hasil hutan dan berburu pada daerah yang sudah ditetapkan. 


\section{KESIMPULAN}

Sesuai hasil penelitian ini maka dapat disimpulkan bahwa :

1. Tujuan berburu landak moncong panjang yang oleh masyarakat Kampung Waibem dan Saukorem adalah untuk dikonsumsi.

2. Jumlah anggota berburu pada Kampung Waibem dan Saukorem berkisar antara 3-10 orang.

3. Waktu berburu landak moncong panjang adalah pada malam hari (22.00-24.00) dan subuh (03.00-08.00) WIT.

4. Perburuan dilakukan secara visual (bantuan mata) dan bantuan anjing berburu dengan menggunakan alat tradisional berupa parang, jerat, tombak, panah pada masyarakat Kampung Waibem, sedangkan pada Kampung Saukorem diperbolehkan menggunakan alat modern berupa senapan angin.

5. Ditemukannya landak moncong panjang tergantung pada kemujuran sehingga dapat mencapai 3-5 ekor.

6. Kegiatan berburu satwa yang dilakukan oleh masyarakat Kampung Waibem dan Saukorem cukup tinggi intensitasnya. Hal ini akan mengakibatkan berkurangnya populasi satwa-satwa tersebut sehingga perlu dilakukan suatu pengembangan ekowisata terhadap satwa-satwa yang terancam punah yang dibuat oleh pemerintah terhadap masyarakat.

7. Satwa landak moncong panjang diprediksikan akan mengalami kepunahan secara alamiah karena faktor alam dan faktor non alami seperti perburuan, degradasi habitat dan lainnya. Oleh sebab itu diperlukan adanya kerjasama antara pihak pemerintah dan masyarakat tentang cara melindungi, melestarikan serta pengembangan ekowisata landak moncong panjang. Selanjutnya, diperlukan sosialisasi dari pihak pemerintah, Balai Konservasi Sumber Daya Alam (BKSDA), dan Lembaga Swadaya Masyarakat (LSM) tentang perlindungan status landak moncong panjang sebagai satwa harapan yang memiliki nilai estetika dan nilai intrinsik lainnya.

\section{DAFTAR PUSTAKA}

Asem G, Kahisiuw P, Fatem SM, Runtuboy Y, \& Marwa J. 2011. Prospect of Tambrauw as conservation regency in West Papua (A preliminary analysis). Dalam : Fauzi MT, Jaya KD, Yong HS, Krisbauch M, Sarjan M, Ujianto L, Latifa S, \& Krisdayanti BD (Ed). Proceeding of the $2^{\text {nd }}$ International Conference on Biodiversity Siginificance of Climate Change on Biodiversity in Sustaining the Globe. Universitas Mataram, Mataram, 2-4 Juli 2013.

Baillie EMJ, Turvey ST, \& Waterman C. 2009. Survival of Attenborough's long-beaked echidna Zaglossus attenboroughi in New Guinea. Fauna dan Flora Internasional, Oryx, 43(1), 146-148.

Fatem S. 2003. Karakteristik Morfologi dan Habitat Landak Moncong Panjang (Zaglossus bruijni). Skripsi (Tidak Dipulikasikan). Fakultas Kehutanan, Universitas Negeri Papua, Manokwari.

Flannery T. 1995. Mammals New Guinea. Revised and Updated Edition. Australian Museum.

Menteri Kehutanan. PP No. 13 Tahun 1994. Pasal 7 dan Peraturan Menteri Kehutanan No. P. 19/ Menhut-II/ 2010: Tentang Penggolongan dan Tatacara Penetapan Jumlah Satwa Buru Pasal 5.

Menzies J. 1991. A Hand Book of New Guinea Marsupials \& Monotremes. Christen Press Inc., Madang, Papua New Guinea.

Opiang MD. 2009. Home ranges, movement, and den use in Long-Beaked Echidnas, Zaglossus bartoni, from Papua New Guinea. Journal of Mammalogy 90(2), 340-346.

Pattiselanno F. 2004. Wildlife Utilization and Food Security in West Papua, Indonesia. Presented Paper on the SEARCA Agriculture and Development seminar series. SEARCE Los Banos, United States.

Petocz RG. 1994. Mamalia Darat Irian Jaya. PT. Gramedia Pustaka Utama, Jakarta. 
Ronsumbre F. 2007. Tingkah Laku Harian Landak Moncong Panjang (Zaglossus bruinii) Jantan Asal Cagar Alam Pegunungan Arfak Secara Ex situ. Skripsi (Tidak Dipublikasikan). Fakultas Matematika dan Ilmu Pengetahuan Alam, Universitas Negeri Papua, Manokwari.

The Zoological Society of London. 2012. http://edgeofexexistence.org/mammal/species info.php?id=1395. Diakses: 23 Mei 2014:04,00 WIT. 